\title{
Determination of Catechin in Green Tea using a Catechol Oxidase Biomimetic Sensor
}

\author{
Suellen C. Fernandes, Renata El-Hage M. de Barros Osório, Ademir dos Anjos, Ademir Neves, \\ Gustavo Amadeu Micke and Iolanda C. Vieira*
}

\author{
Departamento de Química, Universidade Federal de Santa Catarina, 88040-900 Florianópolis-SC, Brazil
}

\begin{abstract}
Um sensor biomimético catecol oxidase, baseado em um novo complexo cobre(II) foi desenvolvido para determinação de catequina em chá verde e os resultados comparados com os obtidos por eletroforese capilar. O complexo dinuclear de cobre(II) $\left[\mathrm{Cu}_{2}(\mathrm{HL})\left(\mu-\mathrm{CH}_{3} \mathrm{COO}\right)\right]$ $\left(\mathrm{ClO}_{4}\right)$, contendo o ligante N,N-[bis-(2-piridilmetil)]-N',N'-[(2-hidroxibenzil)(2-hidroxi-3,5di-tert-butilbenzil)]-1,3-propanodiamino-2-ol $\left(\mathrm{H}_{3} \mathrm{~L}\right)$, foi sintetizado e caracterizado por $\mathrm{IV},{ }^{1} \mathrm{H}$ RMN e análise elementar. As melhores condições para otimização do sensor biomimético foram estabelecidas por voltametria de onda quadrada. O melhor desempenho desse sensor foi obtido em 75:15:10\% (m/m/m) de pó de grafite:nujol:complexo de cobre(II), tampão fosfato $0,05 \mathrm{~mol} \mathrm{~L}^{-1}$ $(\mathrm{pH} \mathrm{7,5)} \mathrm{e} \mathrm{frequiência,} \mathrm{amplitude} \mathrm{de} \mathrm{potencial,} \mathrm{incremento} \mathrm{em} 30 \mathrm{~Hz}, 80 \mathrm{mV}, 3,3 \mathrm{mV}$, respectivamente. A curva analítica foi linear na faixa de concentração $4,95 \times 10^{-6}$ a $3,27 \times 10^{-5} \mathrm{~mol} \mathrm{~L}^{-1}$ $(\mathrm{r}=0,9993)$ com limite de detecção de $2,8 \times 10^{-7} \mathrm{~mol} \mathrm{~L}^{-1}$. Esse sensor biomimético demonstrou longo tempo de estabilidade ( 9 meses; 800 determinações) e reprodutibilidade com um desvio padrão relativo de $3,5 \%$. A recuperação da catequina em amostras de chá verde variou de 93,8 a $106,9 \%$ e a determinação, comparada com a obtida usando eletroforese capilar, mostrou-se aceitável a um nível de confiança de $95 \%$.
\end{abstract}

A catechol oxidase biomimetic sensor, based on a novel copper(II) complex, was developed for the determination of catechin in green tea and the results were compared with those obtained by capillary electrophoresis. The dinuclear copper(II) complex, $\left[\mathrm{Cu}_{2}(\mathrm{HL})\left(\mu-\mathrm{CH}_{3} \mathrm{COO}\right)\right]\left(\mathrm{ClO}_{4}\right)$, containing the ligand N,N-[bis-(2-pyridylmethyl)]-N',N'-[(2-hydroxybenzyl)(2-hydroxy-3,5-ditert-butylbenzyl)]-1,3-propanediamine-2-ol $\left(\mathrm{H}_{3} \mathrm{~L}\right)$, was synthesized and characterized by $\mathrm{IR},{ }^{1} \mathrm{H}$ NMR and elemental analysis. The best conditions for the optimization of the biomimetic sensor were established by square wave voltammetry. The best performance for this sensor was obtained in 75:15:10\% (m/m/m) of the graphite powder:nujol:copper(II) complex, $0.05 \mathrm{~mol} \mathrm{~L}^{-1}$ phosphate buffer solution $(\mathrm{pH} 7.5)$ and frequency, pulse amplitude, scan increment at $30 \mathrm{~Hz}, 80 \mathrm{mV}$, $3.3 \mathrm{mV}$, respectively. The analytical curve was linear in the concentration range $4.95 \times 10^{-6}$ to $3.27 \times 10^{-5} \mathrm{~mol} \mathrm{~L}^{-1}(\mathrm{r}=0.9993)$ with a detection limit of $2.8 \times 10^{-7} \mathrm{~mol} \mathrm{~L}^{-1}$. This biomimetic sensor demonstrated long-term stability ( 9 months; 800 determinations) and reproducibility with a relative standard deviation of $3.5 \%$. The recovery of catechin from green tea samples ranged from 93.8 to $106.9 \%$ and the determination, compared with that obtained using capillary electrophoresis, was found to be acceptable at the $95 \%$ confidence level.

Keywords: catechin, green tea, biomimetic sensor, square wave voltammetry

\section{Introduction}

Tea is one of the most consumed beverages in the world and was firstly used in China for its medicinal properties 5000 years ago. Recent epidemiological studies have shown that the consumption of tea may help to prevent cancers in humans because the tea leaf contains abundant groups of polyphenols. The beneficial effects (e.g. anti-inflammatory,

*e-mail: iolanda@qmc.ufsc.br anti-obesity, reduced incidence of a variety of cancers and cardiovascular diseases) of consuming green tea have been demonstrated. ${ }^{1-4}$ These have been attributed to caffeine, phenolic compounds and anti-oxidative components. The most common polyphenols in green tea are catechins, which may reach concentration levels of $30 \%$ (by mass) of dry material. ${ }^{4}$ Catechins are believed to act as antioxidants and free radical scavengers providing chemo-preventative behavior as well as protection against coronary heart disease and attenuation of high blood pressure. 
Many methods for the determination of tea catechin have been published..$^{1-9}$ High-performance liquid chromatography and capillary electrophoresis with ultraviolet detection are the most cited techniques for separation, identification and quantitation. However, mass spectrometry, and electrochemical, fluorescence and chemiluminescence detection are also used in cases where more sensitive or selective detection is needed. Analytical techniques, such as gas chromatography, spectrophotometry, nuclear magnetic resonance spectroscopy and biosensors have also been used for the determination of catechin..$^{1-9}$

The development of functional models of metalloenzymes for catalyst oxidation reactions is a subject of great interest. ${ }^{10-16}$ Neves et al. ${ }^{17-25}$ have extensively synthesized and characterized model complexes to mimic the active site of the different enzymes (e.g., catechol oxidase, peroxidase, galactose oxidase, catalase, purple acid phosphatase). The majority of $\mathrm{O}_{2}$-reactive copper models have been based on the binuclear- $\mathrm{Cu}$ catechol oxidase. This enzyme has a coupled binuclear copper center in its active site and catalyzes the oxidation of diphenols by molecular oxygen with the production of $o$-quinones. The nature, number and geometric arrangement of ligand atoms define the type(s) of $\mathrm{Cu}: \mathrm{O}_{2}$ species formed. Amine, pyridyl, pyrazolyl and imidazole nitrogen-type donor ligands with bi-, tri- and tetradentate ligands have been successfully used to stabilize $\mathrm{Cu}: \mathrm{O}_{2}$ intermediates at low temperature and in aprotic solvents. ${ }^{10,16-20}$

Many biomimetic catalysts of catechol oxidase have been reported in the literature. ${ }^{10,16-20}$ However, very few report their uses in biomimetic sensors. ${ }^{12,13,26}$ Biomimetic catechol oxidase catalysts have been shown to be efficient catalysts for the oxidation of phenolic substrates to quinones..$^{12,13}$ Sotomayor et al. ${ }^{12}$ employed $\left[\mathrm{CuDipyCl}_{2}\right]$ as a biomimetic catalyst in the construction of an amperometric enzymeless biosensor for phenol determination. This sensor was prepared modifying a glass carbon electrode with a Nafion ${ }^{\circledR}$ membrane doped with $\left[\mathrm{CuDipyCl} \mathrm{Cl}_{2}\right]$ and a linear response range between $4.0 \times$ $10^{-5}$ to $6.0 \times 10^{-4} \mathrm{~mol} \mathrm{~L}^{-1}$ was obtained. In addition, the authors ${ }^{13}$ used a tris (2,2-bipyridyl) copper(II) chloride complex as a biomimetic catalyst in the construction of an amperometric sensor for dopamine. This sensor gave a rectilinear analytical curve for dopamine concentration from 9 to $230 \mu \mathrm{mol} \mathrm{L}^{-1}$ and a detection limit of $4.8 \mu \mathrm{mol} \mathrm{L}{ }^{-1}$. Recently, a dinuclear copper(II) complex was synthesized, characterized and successfully used in the construction of a biomimetic sensor for determining hydroquinone in cosmetics. ${ }^{26}$ This sensor showed better general performance compared with biosensors employing enzymes obtained from vegetable tissue. ${ }^{27-30}$
Metallophthalocyanines are a class of macrocyclic compounds, possessing a system of conjugated $\pi$-electrons, which are very versatile catalysts for several electrochemical reactions and have been successfully employed in the development of chemical sensors. Nyokong and coworkers have used $\mathrm{Co}(\mathrm{II}), \mathrm{Fe}(\mathrm{II}), \mathrm{Ni}(\mathrm{II})$ and $\mathrm{Mn}$ (III) tetrakis benzylmercapto and dodecylmercapto ${ }^{31}$ or tetrakis (dodecylmercapto), ${ }^{32}$ nickel(II) tetrakis benzylmercapto and dodecylmercapto ${ }^{33}$, benzyl- and dodecyl-mercapto tetra substituted cobalt, iron, manganese, nickel and zinc $^{34}$ metallophthalocyanine complexes as biomimetic catalysts. These complexes were deposited on the surface of gold electrodes by the self-assembled monolayer technique and used to investigate the oxidation of sulphite, nitrite and 4-chlorophenols. The catalytic activity of Co(II) tetra ethoxythiophene and Co(II) tetra phenoxypyrrole phthalocyanine complexes towards oxidation of 2-mercaptoethanol, L-cysteine and reduced glutatione has been reported by this group. ${ }^{35}$

This paper describes the determination of catechin in green tea using a novel biomimetic sensor constructed with the copper complex $\left[\mathrm{Cu}_{2}(\mathrm{HL})\left(\mu-\mathrm{CH}_{3} \mathrm{COO}\right)\right]\left(\mathrm{ClO}_{4}\right)$ containing a novel ligand $\mathrm{N}, \mathrm{N}-[$ bis-(2-pyridylmethyl)]-N',N'-[(2hydroxybenzyl)(2-hydroxy-3,5-di-tert-butylbenzyl)]-1,3propanediamine-2-ol $\left(\mathrm{H}_{3} \mathrm{~L}\right)$. This copper complex was synthesized, characterized and used as a catechol oxidase catalyst. The influence of different experimental parameters on the performance of the biomimetic sensor, such as graphite paste complex composition, $\mathrm{pH}$, buffer concentration, frequency, pulse amplitude and scan increment, were investigated using square wave voltammetry. The results obtained for catechin determination in green tea samples using the biomimetic sensor and capillary electrophoresis methods are in good agreement.

\section{Experimental}

\section{Chemicals and solutions}

All chemicals were of analytical grade and all solutions were prepared with water from a Millipore (Bedford, MA, USA) Milli-Q system (model UV Plus Ultra-Low Organic Water). Caffeine, catechin, epicatechin, epigallocatechin, epicatechin gallate, epigallocatechin gallate, gallic acid, guaiacol, ferulic acid, p-coumaric acid, syringic acid, vanilic acid, sucrose, glucose, fructose, benzoic acid, citric acid, tartaric acid, fumaric acid, dichloromethane and tetrabutylammonium hexafluorphosphate were acquired from Sigma. Sodium dodecylsulfate (SDS) and triethylamine (TEA) were obtained from Merck. Catechin was purchased from Sigma and a $0.05 \mathrm{~mol} \mathrm{~L}^{-1}$ stock 
solution was prepared daily in $0.05 \mathrm{~mol} \mathrm{~L}^{-1}$ phosphate buffer solution at $\mathrm{pH} 7.5$. Reference solutions from $4.95 \times 10^{-6}$ to $3.27 \times 10^{-5} \mathrm{~mol} \mathrm{~L}^{-1}$ were prepared from the stock solution by appropriate dilution with the same buffer solution. Phosphate buffer $\left(0.05 \mathrm{~mol} \mathrm{~L}^{-1}, \mathrm{pH} 7.5\right)$ solution was used as the supporting electrolyte. For the capillary electrophoresis analysis a stock solution of SDS and TEA was prepared at $1.0 \mathrm{~mol} \mathrm{~L}^{-1}$, and the internal standard (propylparaben) was prepared in methanol at $120 \mathrm{mg} \mathrm{L}^{-1}$.

\section{Apparatus}

Elemental analysis was performed with a Carlo Erba E1110 analyzer. IR spectra were measured in the range 4000-400 $\mathrm{cm}^{-1}$ with $\mathrm{KBr}$ pellets, using a Perkin-Elmer 781 spectrometer. ${ }^{1} \mathrm{H}$ NMR analysis of the ligand was carried out with a Bruker $200 \mathrm{MHz}$ spectrometer in $\mathrm{CDCl}_{3}$ chloroform, at $25^{\circ} \mathrm{C}$. Chemical shifts were referenced to tetramethylsilane (TMS).

\section{Electrochemical instrumentation}

Square wave voltammetry measurements were performed using an Autolab PGSTAT12 potentiostat/ galvanostat (Eco Chemie, Utrecht, The Netherlands). A three-electrode assembly was used in which a biomimetic sensor, and $\mathrm{Ag} / \mathrm{AgCl}\left(3.0 \mathrm{~mol} \mathrm{~L}^{-1} \mathrm{KCl}\right)$ and platinumwire electrodes, served as the working, reference and auxiliary electrodes, respectively. A cyclic voltammetry measurement of the copper(II) complex was performed with an EG\&G PAR, model 273A, potentiostat/ galvanostat. Cyclic voltammograms were obtained in dichloromethane containing the copper(II) complex and $0.1 \mathrm{~mol} \mathrm{~L}^{-1}$ tetrabutylammonium hexafluorphosphate as the supporting electrolyte under an argon atmosphere. The electrochemical cell employed was of a standard three-electrode configuration: platinum (working), $\mathrm{Ag} / \mathrm{AgCl}$ (reference) and platinum wire (auxiliary) electrodes. The redox couple $\left(\mathrm{Fc}^{+} / \mathrm{Fc}\right)$ of ferrocene $(+0.40 \mathrm{~V} v s . \mathrm{NHE})$ was used as the internal standard. The system was monitored with a personal computer for data acquisition and subsequent analysis. All measurements were carried out at room temperature $\left(25.0 \pm 0.5^{\circ} \mathrm{C}\right)$.

\section{Capillary electrophoresis equipment}

The validation of the proposed analytical method was carried out using an Agilent Technologies $\mathrm{HP}^{3 \mathrm{D}} \mathrm{CE}$ capillary electrophoresis automated apparatus (Palo Alto, CA, USA), equipped with a diode array detector. The measurements were performed at $25{ }^{\circ} \mathrm{C}$ on an uncoated fused-silica capillary $(48.5 \mathrm{~cm} \times 50 \mu \mathrm{m}$ I.D. $\times 375 \mu \mathrm{m}$ O.D, $40 \mathrm{~cm}$ of effective length) obtained from Polymicro Technologies (Phoenix, AZ, USA). The acquisition software for data treatment was HP Chemstation ${ }^{\circledR}$.

Synthesis of the ligand $\left(\mathrm{H}_{3} \mathrm{~L}\right)$ and of the complex $\left[\mathrm{Cu}_{2}(\mathrm{HL})\right.$ $\left.\left(\mu-\mathrm{CH}_{3} \mathrm{COO}\right)\right]\left(\mathrm{ClO}_{4}\right)$

The reaction scheme for preparation of the $\mathrm{H}_{3} \mathrm{~L}$ ligand is shown in Figure 1. The products $\mathrm{N}, \mathrm{N}$-[bis(2-pyridylmethyl)]-N'-[(2-hydroxybenzyl)]-1,3propanediamine-2-ol (1) ${ }^{20}$ and 3,5-di-tert-butyl-2hydroxybenzyl chloride (2) ${ }^{21,22}$ were synthesized according to the methods described in the literature. ${ }^{1} \mathrm{H} \mathrm{NMR}\left(\mathrm{CDCl}_{3}\right.$, $\delta \mathrm{ppm}$ ) for product $\mathbf{1}^{20}: 2.6-2.7(4 \mathrm{H}), 3.8-4.0(7 \mathrm{H}), 6.7-6.8$ $(2 \mathrm{H}), 7.0-7.2(6 \mathrm{H}), 7.5(2 \mathrm{H}), 8.5(2 \mathrm{H}) .{ }^{1} \mathrm{H} \mathrm{NMR}\left(\mathrm{CDCl}_{3}, \delta\right.$ $\mathrm{ppm}$ ) for product 2:21,22 $1.33(9 \mathrm{H}), 1.43(9 \mathrm{H}), 4.7(2 \mathrm{H}), 7.0$ $(1 \mathrm{H}), 7.3(1 \mathrm{H})$. Melting point for product $2^{22}: 61-62{ }^{\circ} \mathrm{C}$.

Synthesis of the $\mathrm{H}_{3} \mathrm{~L}$ ligand: to a $\mathrm{CH}_{2} \mathrm{Cl}_{2}$ solution containing $2.0 \times 10^{-2} \mathrm{~mol} \mathrm{~L}^{-1}$ of 1 and $3.0 \times 10^{-2} \mathrm{~mol} \mathrm{~L}^{-1}$ of triethylamine, $3.0 \times 10^{-2} \mathrm{~mol} \mathrm{~L}^{-1}$ of $\mathbf{2}$ was added dropwise at room temperature. After $24 \mathrm{~h}$ under stirring at $40{ }^{\circ} \mathrm{C}$, the resulting solution was washed five times with $50 \mathrm{~mL}$ of sodium bicarbonate solution. The organic phase was dried over anhydrous $\mathrm{Na}_{2} \mathrm{SO}_{4}$ and the solvent was removed under reduced pressure to give a yellow oil corresponding to the $\mathrm{H}_{3} \mathrm{~L}$ ligand. Yield: $14.2 \mathrm{~g} \mathrm{(75 \%} \mathrm{based} \mathrm{on} \mathrm{product} \mathrm{A}$, $\left.\mathrm{MM}=596.81 \mathrm{~g} \mathrm{~mol}^{-1}\right)$. The $\mathrm{H}_{3} \mathrm{~L}$ ligand was confirmed through ${ }^{1} \mathrm{H}$ NMR $\left(\mathrm{CDCl}_{3}\right), \delta(\mathrm{ppm}): 1.2(9 \mathrm{H}), 1.4(9 \mathrm{H})$, $2.6(4 \mathrm{H}), 3.6-4.2(9 \mathrm{H}), 6.8-7.1(10 \mathrm{H}), 7.5(2 \mathrm{H}), 8.5(2 \mathrm{H})$; the phenolic protons were not observed.
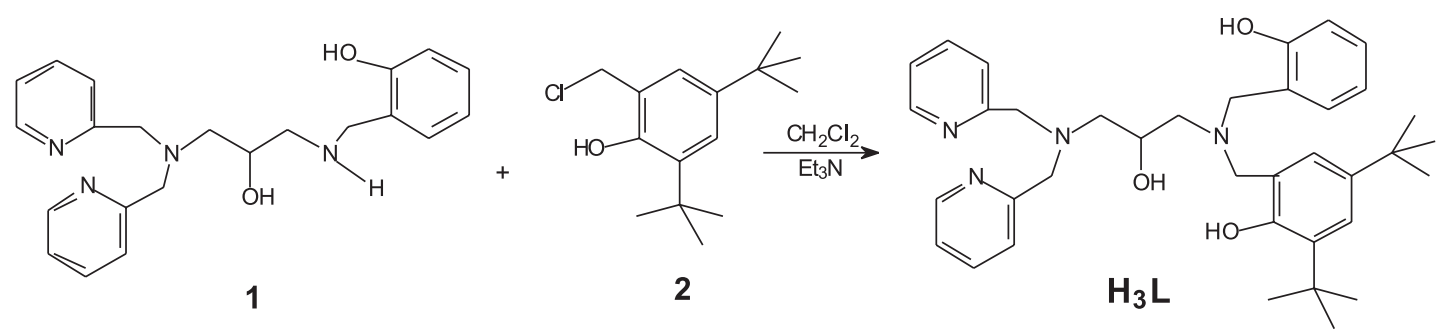

Figure 1. Synthesis of the ligand N,N-[bis-(2-pyridylmethyl)]-N',N'-[(2-hydroxybenzyl)(2-hydroxy-3,5-di-tert-butylbenzyl)]-1,3-propanediamine-2-ol $\left(\mathrm{H}_{3} \mathrm{~L}\right)$. 
Synthesis of the complex $\left[\mathrm{Cu}_{2}(\mathrm{HL})\left(\mu-\mathrm{CH}_{3} \mathrm{COO}\right)\right]\left(\mathrm{ClO}_{4}\right)$ : a $20 \mathrm{~mL}$ aliquot of a methanol solution of $1.0 \times 10^{-3} \mathrm{~mol} \mathrm{~L}^{-1}$ $\mathrm{H}_{3} \mathrm{~L}$ ligand was added to $20 \mathrm{~mL}$ of a methanol solution of 2.0 $\times 10^{-3} \mathrm{~mol} \mathrm{~L}^{-1} \mathrm{Cu}\left(\mathrm{CH}_{3} \mathrm{COO}\right)_{2} \cdot \mathrm{H}_{2} \mathrm{O}$ under stirring. The dark green solution was heated to $50{ }^{\circ} \mathrm{C}, 2.0 \times 10^{-3} \mathrm{~mol} \mathrm{~L}^{-1}$ sodium perchlorate was then added and the solution was concentrated to around $20 \mathrm{~mL}$. After cooling the solution to room temperature, a stable green microcrystalline precipitate was formed, which was filtered off and washed with cold isopropanol and ethyl ether. Yield: $50 \%$ (based on $\mathrm{H}_{3} \mathrm{~L}$ ligand). The dinuclear copper(II) complex was confirmed and characterized through IR, CHN and X-ray crystallographic analysis. ${ }^{24}$ Anal. Calc. for $\mathrm{Cu}_{2} \mathrm{C}_{42} \mathrm{H}_{59} \mathrm{ClN}_{4} \mathrm{O}_{11}\left(\mathrm{MM}=958.46 \mathrm{~g} \mathrm{~mol}^{-1}\right): \mathrm{C}: 52.63 \%$; $\mathrm{H}$ : 6.20\%; N: 5.85\%. Found: C: $51.07 \%$; H: 5.71\%; N: $5.87 \%$. $\mathrm{IR}(\mathrm{KBr}) v_{\text {max }} / \mathrm{cm}^{-1}:(\mathrm{OH}$, alcohol) 3438s; (CH, t-butyl) 2956s; $\left(\mathrm{COO}^{-} \text {, acetate }\right)_{\text {asymm }} 1572 \mathrm{~s} ;\left(\mathrm{COO}^{-} \text {, acetate }\right)_{\text {symm }} 1436$ s; (CO) $1284 \mathrm{~m} ;\left(\mathrm{ClO}^{-}\right.$, perchlorate $) 1092 \mathrm{~s}$.

\section{Preparation of the biomimetic sensor}

The biomimetic sensor was prepared as previously described by our group:26-30 firstly, the graphite powder (375 mg; $75 \% \mathrm{~m} / \mathrm{m}$ ) and the copper complex powder $(50 \mathrm{mg}$; $10 \% \mathrm{~m} / \mathrm{m}$ ) were mixed and homogenized in a mortar for $20 \mathrm{~min}$ to ensure uniform dispersion. Subsequently, Nujol (75 mg; $15 \% \mathrm{~m} / \mathrm{m}$ ) was added and the mixture was mixed for additional $20 \mathrm{~min}$ to produce the final paste. The resulting modified carbon paste was packed firmly into the cavity (3.0 $\mathrm{mm}$ diameter) of a plastic syringe and the external electrical contact was established through a silver wire.

\section{Electrochemical measurement}

Square wave voltammetry measurements were performed in an unstirred, non de-aerated phosphate buffer solution (pH 7.5) at $25.0 \pm 0.5^{\circ} \mathrm{C}$ and all potentials were measured and reported vs. $\mathrm{Ag} / \mathrm{AgCl}\left(3.0 \mathrm{~mol} \mathrm{~L}^{-1} \mathrm{KCl}\right)$. In a typical run, a $10 \mathrm{~mL}$ of the supporting electrolyte was transferred into a clean, dry cell and the required volume of the catechin or sample solutions was added by micropipette. After a stirring period of $60 \mathrm{~s}$ in order to homogenize the solution, a square wave or cyclic voltammogram was recorded. The square wave voltammetry measurements were performed applying a sweep potential between +0.29 and $0 \mathrm{~V}$, at a pulse amplitude of 10 to $100 \mathrm{mV}$, frequency of 10 to $100 \mathrm{~Hz}$ and scan increment of 0.3 to $3.6 \mathrm{mV}$, after successive additions of catechin.

\section{Capillary electrophoresis measurement}

Electropherograms were recorded as described: standard solutions and samples were injected hydrodynamically at
$50 \mathrm{mbar}$ for $3 \mathrm{~s}$ and the applied separation voltage was $25 \mathrm{kV}$, negative polarity. The detector wavelength was fixed at $206 \mathrm{~nm}$. The background electrolyte (BGE) consisted of a mixture of $50.0 \times 10^{-3} \mathrm{~mol} \mathrm{~L}^{-1}$ sodium dodecylsulfate, $10.0 \times 10^{-3} \mathrm{~mol} \mathrm{~L}^{-1}$ triethylamine and $\mathrm{pH} 2.5$ adjusted with phosphoric acid. At the start of each new working session, the capillary was conditioned at $25^{\circ} \mathrm{C}$ and flushed with $1.0 \mathrm{~mol} \mathrm{~L}^{-1}$ sodium hydroxide for $10 \mathrm{~min}$, followed by deionized water for $5 \mathrm{~min}$ and finally with the BGE for 10 min. Between runs with the same buffer, the capillary was rinsed for $2 \mathrm{~min}$ with BGE. At the end of the analysis, the capillary was rinsed for $5 \mathrm{~min}$ with $1.0 \mathrm{~mol} \mathrm{~L}^{-1}$ sodium hydroxide and $10 \mathrm{~min}$ with deionized water.

\section{Preparation of green tea samples and measurement}

Three types of green tea samples (A, B and C) were selected and purchased in Florianópolis, SC, Brazil. The samples were prepared by extracting $2.0 \mathrm{~g}$ of the tea with $40 \mathrm{~mL}$ of the $0.1 \mathrm{~mol} \mathrm{~L}^{-1}$ phosphate buffer solution (pH 7.5) at $35^{\circ} \mathrm{C}$, incubating for $20 \mathrm{~min}$, shaking for $2 \mathrm{~min}$, filtering and centrifuging. An aliquot of $10 \mathrm{~mL}$ of the green tea extract was transferred to an electrochemical cell and analyzed after successive additions of the reference catechin solution. After each addition, square wave voltammograms were recorded by scanning the potential from +0.29 and $0 \mathrm{~V}$, at a pulse amplitude of $80 \mathrm{mV}$, a frequency of $30 \mathrm{~Hz}$ and a scan increment of $3.3 \mathrm{mV}$. All measurements were performed in triplicate.

A capillary electrophoresis system was also used for the determination of catechin in the green tea samples. These samples were diluted, 1:4:1 (v/v/v) sample:distilled water:internal standard, before injection. For the quantitation, the calibration curve with concentrations of the catechin between 15 and $60 \mathrm{mg} \mathrm{L}^{-1}$ and a constant internal standard concentration $\left(20 \mathrm{mg} \mathrm{L}^{-1}\right)$, were used. Each concentration was prepared in triplicate and injected in triplicate.

\section{Results and Discussion}

Synthesis and characterization of the ligand and the
dinuclear copper(II) complex

The known products N,N-[bis-(2-pyridylmethyl)]-N'[(2-hydroxybenzyl)]-1,3-propanediamine-2-ol (1) and 3,5-di-tert-butyl-2-hydroxybenzyl chloride (2) were prepared in good yield and the characterization was unambiguously established by NMR spectroscopy and melting point techniques, as reported in the literature. ${ }^{21-22}$ The ligand N,N-[bis-(2-pyridylmethyl)]-N',N'-[(2-hydroxybenzyl) 
(2-hydroxy-3,5-di-tert-butylbenzyl)]-1,3-propanediamine-2ol $\left(\mathrm{H}_{3} \mathrm{~L}\right)$ was obtained in good yield using epichlorohydrin, which is widely used as a convenient precursor for the synthesis of unsymmetric ligands containing the central skeleton 1,3-diaminopropan-2-ol. ${ }^{20,21,24}$ The $\mathrm{H}_{3} \mathrm{~L}$ ligand's structure was confirmed through ${ }^{1} \mathrm{H}$ NMR spectroscopy and prepared in order to synthesize dinuclear copper(II) complexes in which the molecular spacer alkoxo oxygen atom holds the two metal centers in close proximity and the fifth and sixth coordination positions are available for the coordination of exogenous ligands.

The $\mathrm{H}_{3} \mathrm{~L}$ ligand reacts in methanolic solution with $\mathrm{Cu}\left(\mathrm{CH}_{3} \mathrm{COO}\right)_{2} \cdot \mathrm{H}_{2} \mathrm{O}$ (stoichiometry $1: 2$ ) and addition of $\mathrm{NaClO}_{4}$ results in the formation of the dinuclear complex $\left[\mathrm{Cu}_{2}{ }^{\mathrm{II}}(\mathrm{HL})\left(\mu-\mathrm{CH}_{3} \mathrm{COO}\right)\right]\left(\mathrm{ClO}_{4}\right)$. This complex was confirmed and characterized through IR, elemental and X-ray crystallographic analysis. The IR spectrum of the complex shows $v_{\text {asymm }}\left(\mathrm{COO}^{-}\right)$and $v_{\text {symm }}\left(\mathrm{COO}^{-}\right)$at 1572 and $1436 \mathrm{~cm}^{-1}$, respectively. The splitting between $v_{\text {asymm }}\left(\mathrm{COO}^{-}\right)$and $v_{\text {symm }}\left(\mathrm{COO}^{-}\right)$is $136 \mathrm{~cm}^{-1}$, indicating that the carboxylate group bridges the two $\mathrm{Cu}(\mathrm{II})$ ions. In addition, stretching vibrations of the uncoordinated $\mathrm{ClO}_{4}^{-}$ are located at $1092 \mathrm{~cm}^{-1}$, confirming the cationic character of this complex according to the stoichiometry determined from elemental analysis. The asymmetry of the $\mathrm{H}_{3} \mathrm{~L}$ ligand leads to non-equivalent environments of both copper centers in the complex. In the asymmetric unit both copper(II) centers are pentacoordinated with one $\mathrm{Cu}$ being in a square pyramidal geometry and the other one in a distorted trigonal bipyramidal geometry. The structure of the complex (inset Figure 2) reveals that the two copper centers are $3.48 \AA$ apart and are bridged by an alkoxide oxygen atom of the $\mathrm{H}_{3} \mathrm{~L}$ ligand and by an additional bidentate acetate, to form a double-bridged binuclear core. The structure shows distinct coordination modes of the phenol groups around the $\mathrm{Cu}$ center in a square-pyramidal geometry, thus resulting in significantly different $\mathrm{Cu}-\mathrm{O}$ bond distances: one terminal phenol oxygen atom (containing tert-butyl groups) is protonated in the apical position $\left(\mathrm{Cu}-\mathrm{O}_{\text {phenol }}=2.45 \AA\right.$ ), while the other is coordinated as a phenolate and occupies the basal plane $\left(\mathrm{Cu}-\mathrm{O}_{\text {phenolate }}=1.90 \AA\right)$. Therefore, the complex can be regarded as a structural model for the active site of the met form of catechol oxidase.

\section{Cyclic voltammetry of the dinuclear copper(II) complex}

Figure 2 shows the cyclic voltammogram for $5.0 \times 10^{-4} \mathrm{~mol} \mathrm{~L}^{-1}$ dinuclear copper(II) complex in dichloromethane and $0.1 \mathrm{~mol} \mathrm{~L}^{-1}$ tetrabutylammonium hexafluorphosphate performed by scanning the potential between +0.8 and $-1.2 \mathrm{~V} v$ s. $\mathrm{Ag} / \mathrm{AgCl}$ at a scan rate

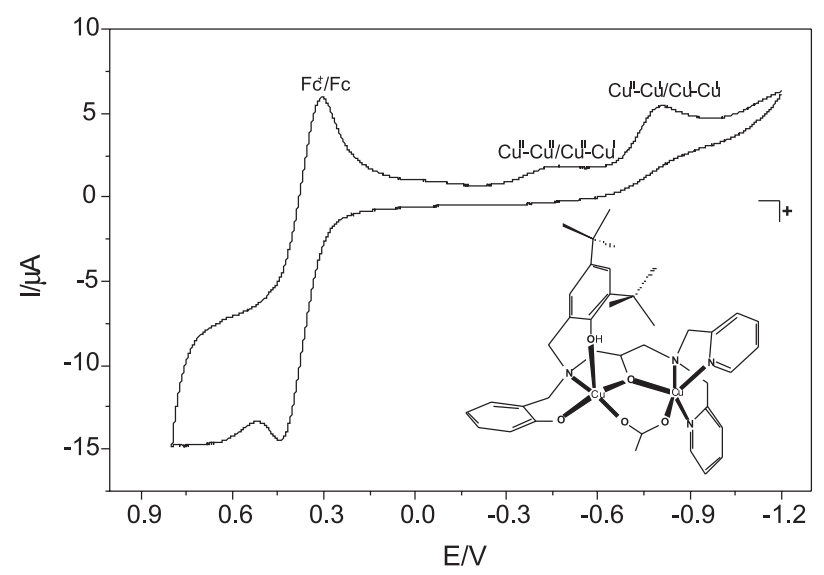

Figure 2. Cyclic voltammogram for $5.0 \times 10^{-4} \mathrm{~mol} \mathrm{~L}^{-1}$ dinuclear copper (II) complex in dichloromethane and $0.1 \mathrm{~mol} \mathrm{~L}^{-1}$ tetrabutylammonium hexafluorphosphate performed by scanning the potential between +0.8 and $-1.2 v s . \mathrm{Ag} / \mathrm{AgCl}$ at a scan rate of $100 \mathrm{mV} \mathrm{s}^{-1}$. Inset: the dinuclear copper(II) cation $\left[\mathrm{Cu}_{2}(\mathrm{HL})\left(\mathrm{CH}_{3} \mathrm{COO}\right)\right]^{+}$containing the $\mathrm{H}_{3} \mathrm{~L}$ ligand.

of $100 \mathrm{mV} \mathrm{s}^{-1}$. The inset shows a schematic diagram of the $\left[\mathrm{Cu}_{2}(\mathrm{HL})\left(\mathrm{CH}_{3} \mathrm{COO}\right)\right]^{+}$cation. It can be seen that the complex shows a quasi-reversible process at $\mathrm{E}_{\mathrm{pc}}=-0.37$ $\mathrm{mV}$, corresponding to the redox couple $\mathrm{Cu}^{\mathrm{II}} \mathrm{Cu}^{\mathrm{p}} / \mathrm{Cu}^{\mathrm{II}} \mathrm{Cu}^{\mathrm{I}}$, and an irreversible process at $\mathrm{E}_{\mathrm{pc}}=-0.72 \mathrm{~V}$ relating to the $\mathrm{Cu}^{\mathrm{II}} \mathrm{Cu}^{\mathrm{I}} / \mathrm{Cu}^{\mathrm{I}} \mathrm{Cu}^{\mathrm{I}}$ process. A tendency toward negative reduction potentials was observed for copper complexes with an alkoxide bridge and phenolic ligands, due to the electronegativity and hardness of the oxygen atoms of the bridge and of the ligands.

\section{Optimal conditions of the biomimetic sensor response}

For the catechin determination using the biomimetic sensor with the highest sensitivity, the graphite paste complex composition, $\mathrm{pH}$ and buffer concentration were investigated to obtain optimal conditions. The results of the optimization studies are shown in Table 1.

Table 1. Optimization of biomimetic sensor parameters

\begin{tabular}{lccccc}
\hline $\begin{array}{l}\text { Copper complex } \\
\text { composition } /(\mathrm{m} / \mathrm{m})\end{array}$ & $-\mathrm{Ipc} / \mu \mathrm{A}$ & $\mathrm{pH}$ & $-\mathrm{Ipc} / \mu \mathrm{A}$ & $\begin{array}{c}{[\mathrm{Buffer}] /} \\
\left(\mathrm{mol} \mathrm{L}^{-1}\right)\end{array}$ & $-\mathrm{Ipc} / \mu \mathrm{A}$ \\
\hline 5.0 & 3.8 & 5.0 & 2.2 & 0.02 & 14.7 \\
10.0 & 6.0 & 6.0 & 4.6 & 0.05 & 19.9 \\
15.0 & 3.6 & 7.0 & 24.8 & 0.10 & 19.0 \\
20.0 & 2.7 & 7.5 & 34.9 & 0.25 & 17.9 \\
& & 8.0 & 12.0 & & \\
& & 9.0 & 9.1 & & \\
\hline
\end{tabular}

In the past few years, we have reported the use and composition of carbon paste in the construction of a biosensor and biomimetic sensor and the best composition was 75:25 (\%, $\mathrm{m} / \mathrm{m})$ graphite powder:Nujol. ${ }^{26-30}$ Therefore, this carbon paste composition was used in this study in 
the construction of the biomimetic sensor. The effect of varying the $\mathrm{Cu}(\mathrm{II})$ complex composition from 5.0 to $20.0 \%(\mathrm{~m} / \mathrm{m})$ in a fixed amount of graphite powder:Nujol of $75: 15(\%, \mathrm{~m} / \mathrm{m})$ was investigated. The analytical response (cathodic peak currents) for $1.0 \times 10^{-5} \mathrm{~mol} \mathrm{~L}^{-1}$ catechin increased with the $\mathrm{Cu}(\mathrm{II})$ complex percentage used up to $10 \%$. Thus, a composition of $75: 15: 10$ $(\%, \mathrm{~m} / \mathrm{m})$ graphite:Nujol:Cu(II) complex was used in the construction of the proposed biomimetic sensor.

The effect of $\mathrm{pH}$ in the range of 5.0 to 9.0 of a $1.0 \times 10^{-5} \mathrm{~mol} \mathrm{~L}^{-1}$ catechin solution was studied. The analytical response (cathodic peak current) increased with an increase in the $\mathrm{pH}$ up to 7.5. Consequently, this $\mathrm{pH}$ was used as the working $\mathrm{pH}$.

The effect of varying the phosphate buffer $(\mathrm{pH}$ 7.5) concentration from 0.02 to $0.25 \mathrm{~mol} \mathrm{~L}^{-1}$ of a $1.0 \times 10^{-5} \mathrm{~mol} \mathrm{~L}^{-1}$ catechin solution on the biomimetic sensor response was also investigated. The best response was obtained for a concentration of $0.05 \mathrm{~mol} \mathrm{~L}^{-1}$, which was subsequently used in this study.

Square wave voltammetry parameters were also investigated and in Table 2 the values of the biomimetic sensor response for frequency, pulse amplitude and scan increment, respectively, can be observed.

Table 2. Optimization of square wave voltammetry parameters

\begin{tabular}{|c|c|c|c|c|c|}
\hline $\begin{array}{l}\text { Frenquency/ } \\
\mathrm{Hz}\end{array}$ & $-\mathrm{Ipc} / \mu \mathrm{A}$ & $\begin{array}{c}\text { Pulse } \\
\text { amplitude/ } \\
\mathrm{mV}\end{array}$ & $-\mathrm{Ipc} / \mu \mathrm{A}$ & $\begin{array}{c}\text { Scan } \\
\text { increment/ } \\
\mathrm{mV}\end{array}$ & $-\mathrm{Ipc} / \mu \mathrm{A}$ \\
\hline 10 & 16.8 & 10 & 1.7 & 0.3 & 3.2 \\
\hline 20 & 20.0 & 20 & 3.5 & 1.0 & 6.2 \\
\hline 30 & 20.2 & 30 & 4.3 & 1.1 & 8.2 \\
\hline 40 & 15.0 & 40 & 5.5 & 1.4 & 9.1 \\
\hline 50 & 12.3 & 50 & 6.8 & 1.7 & 9.9 \\
\hline 60 & 10.1 & 60 & 7.5 & 2.4 & 10.3 \\
\hline 70 & 8.2 & 70 & 7.9 & 2.7 & 10.9 \\
\hline 80 & 6.9 & 80 & 10.2 & 3.0 & 11.4 \\
\hline 90 & 5.5 & 90 & 10.3 & 3.3 & 11.6 \\
\hline 100 & 4.3 & 100 & 10.4 & 3.6 & 11.8 \\
\hline
\end{tabular}

The effects of frequency (10 to $100 \mathrm{~Hz}$ ), pulse amplitude $(10$ to $100 \mathrm{mV})$ and scan increment $(0.3$ to $3.6 \mathrm{mV})$ on the biomimetic sensor response to $1.0 \times 10^{-5} \mathrm{~mol} \mathrm{~L}^{-1}$ catechin solutions were studied. The highest analytical signal was obtained at $30 \mathrm{~Hz}$, thus this frequency was selected. The analytical response of this biomimetic sensor increased with an increase in the pulse amplitude used up to 10 to $80 \mathrm{mV}$ and then staying constant between 80 and $100 \mathrm{mV}$. Consequently, the pulse amplitude of $80 \mathrm{mV}$ was used in this study. The sensor showed good response and linearity up to a scan increment of $3.3 \mathrm{mV}$, after which the response value remained constant; thus, the scan increment $3.3 \mathrm{mV}$ was selected.
Reproducibility, repeatability and stability of the biomimetic sensor

Reproducibility was investigated considering three electrodes, prepared independently, and an acceptable reproducibility with a relative standard deviation of $4.2 \%$ for the response to $1.0 \times 10^{-5} \mathrm{~mol} \mathrm{~L}^{-1}$ catechin solution $(\mathrm{pH}$ 7.5) was obtained.

The repeatability of the biomimetic sensor performance was studied for solutions containing $1.0 \times 10^{-5} \mathrm{~mol} \mathrm{~L}^{-1}$ catechin solution ( $\mathrm{pH} 7.5)$. The relative standard deviation was $3.4 \%$ for 12 successive assays.

To clean the electrode surface cyclic voltammetry was performed applying a sweep potential between +1.0 and $-1.0 \mathrm{~V}$ so it could be used without removing the surface. When not in use, the sensor was stored at room temperature.

Long-time stability is considered an important factor of the electrode performance. The stability of the biomimetic sensor was tested by repeated measurements without surface renewal over a 270 -day period (at least 800 determinations) using a $1.0 \times 10^{-5} \mathrm{~mol} \mathrm{~L}^{-1}$ catechin solution in $0.1 \mathrm{~mol} \mathrm{~L}^{-1}$ phosphate buffer solution ( $\mathrm{pH} 7.5$ ). When the sensor was stored at room temperature and measured every 1-2 days, no obvious change was found in the response.

The good reproducibility, repeatability and long-term stability can be attributed to the excellent ability of this $\mathrm{Cu}$ (II) complex to mimic the active site of the catechol oxidase enzyme and its successful use in the construction of the biomimetic sensor.

\section{Selectivity and recovery study}

The selectivity of the optimized method for the determination of catechin was examined in the presence of some substances such as caffeine, epicatechin, epigallocatechin, epicatechin gallate, epigallocatechin gallate, gallic acid, guaiacol, ferulic acid, $p$-coumaric acid, syringic acid, vanilic acid, sucrose, glucose, fructose, benzoic acid, citric acid, tartaric acid and fumaric acid. The ratios of the concentration of catechin to that of each substance were fixed at $0.1,1.0$ and 10.0. None of these substances interfered with the proposed procedure, that is, the biomimetic sensor was able to determine the amount of catechin in the presence of these substances and can therefore be considered selective.

In order to evaluate the effect of the presence of potential interferences on the proposed sensor, the standard additions method was applied. Analytical recovery measurements were obtained by adding different amounts of catechin (29.0 to $238.1 \mathrm{mg} \mathrm{L}^{-1}$ ) to three samples of green tea (A, B 
and $\mathrm{C}$ ). The percentage recovery values were calculated by comparing the concentration obtained from the samples with and without the addition of known concentrations of the catechin standard solution. The recoveries of 93.8 to $106.9 \%$ obtained for these samples are shown in Table 3. It can be clearly observed that the recovery results obtained suggest an absence of matrix effects in these determinations.

Table 3. Results for recoveries of catechin standard solution from green tea using the proposed biomimetic sensor

\begin{tabular}{lccc}
\hline \multirow{2}{*}{ Sample } & \multicolumn{2}{c}{ Catechin/( $\left.\mathrm{mg} \mathrm{L}^{-1}\right)$} & \multirow{2}{*}{ Recovery/(\%) } \\
\hline \multirow{3}{*}{ A } & 29.0 & $31.0 \pm 0.1$ & 106.9 \\
& 56.9 & $53.4 \pm 0.1$ & 93.8 \\
& 84.2 & $85.9 \pm 0.2$ & 102.0 \\
B & 56.9 & $55.7 \pm 0.1$ & 97.9 \\
& 84.2 & $80.7 \pm 0.2$ & 95.8 \\
& 110.1 & $113.1 \pm 0.1$ & 102.7 \\
C & 189.2 & $178.2 \pm 0.1$ & 94.2 \\
& 215.0 & $218.1 \pm 0.1$ & 101.4 \\
\hline
\end{tabular}

$n=3$.

Square wave voltammetry and analytical curve

Figure 3 shows a scheme of the reaction between catechin and the $\mathrm{Cu}(\mathrm{II})$ complex used to mimic the active site of the catechol oxidase incorporated into the carbon paste. In the presence of this complex the catechin is oxidized to $o$-quinone and subsequently the $o$-quinone produced at the electrode surface is electrochemically reduced to catechin at a potential of $+0.13 \mathrm{~V}$.

The electrocatalytic behavior of the carbon paste electrode and biomimetic sensor in relation to the

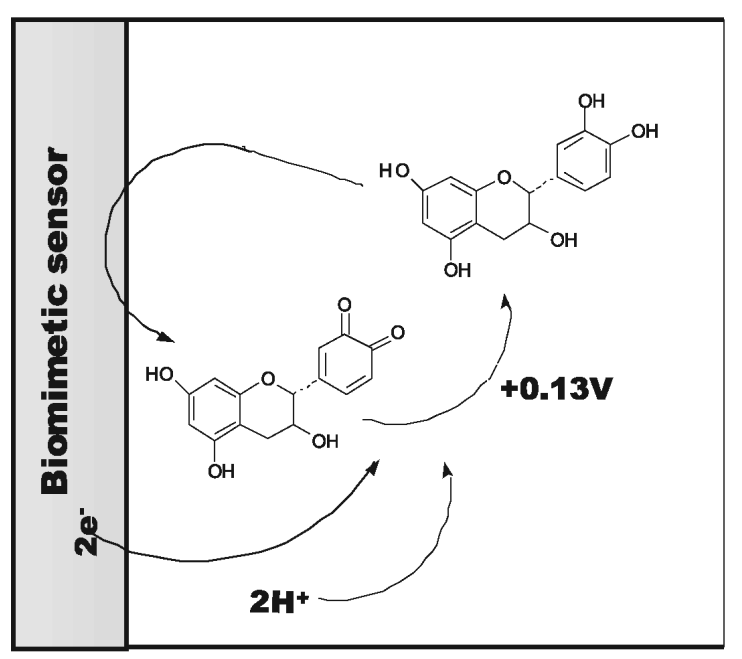

Figure 3. Schematic representation of the reaction between catechin and the copper(II) complex used to mimic the catechol oxidase catalyst at the biomimetic sensor surface. electrochemical reduction of the $o$-quinone was investigated using square wave voltammetry under the optimum conditions established. Figure 4 shows the square wave voltammograms obtained using a carbon paste electrode (b) and biomimetic sensor (a and c) in an unstirred 0.05 mol L $\mathrm{L}^{-1}$ phosphate buffer solution ( $\mathrm{pH} 7.5$ ) without catechin (a) and with $2.38 \times 10^{-5} \mathrm{~mol} \mathrm{~L}^{-1}$ of catechin (b and c). As can be seen, the carbon paste electrode showed an electrochemical reduction of $o$-quinone to catechin at a peak potential of $+0.11 \mathrm{~V}$ under these experimental conditions. When the biomimetic sensor was used (voltammogram c; cathodic peak potential $+0.13 \mathrm{~V}$ ) there was an increase in the sensor response, as expected, due to the presence the copper complex.

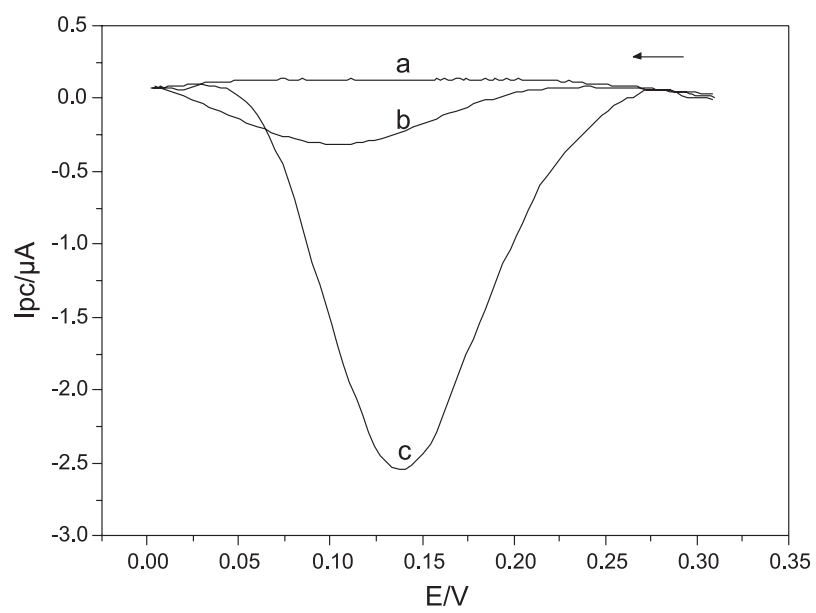

Figure 4. Square wave voltammograms obtained using a carbon paste electrode (b) and biomimetic sensor (a and c) in an unstirred $0.05 \mathrm{~mol} \mathrm{~L}^{-1}$ phosphate buffer solution ( $\mathrm{pH} 7.5$ ) without catechin (a) and with the addition of $2.38 \times 10^{-5} \mathrm{~mol} \mathrm{~L}^{-1}$ of catechin (b and c) at pulse amplitude $80 \mathrm{mV}$, frequency $30 \mathrm{~Hz}$ and increment $3.3 \mathrm{mV}$.

The cathodic peak currents obtained in the square wave voltammetry were proportional the catechin concentrations of $4.95 \times 10^{-6}$ to $3.27 \times 10^{-5} \mathrm{~mol} \mathrm{~L}^{-1}$ and the regression equation was found to be Ipc $=1.599+5.697 \times 10^{4}$ [catechin]; $r=0.9993$, where Ipc is the cathodic peak current in $\mu \mathrm{A}$ and [catechin] is the catechin concentration in mol L ${ }^{-1}$. Figure 5 shows these voltammograms and inset is the analytical curve. The detection limit (three times the signal blank/slope) and quantification limit (ten times the signal blank/slope) were calculated using this calibration curve, and found to be $2.8 \times 10^{-7} \mathrm{~mol} \mathrm{~L}^{-1}$ and $3.5 \times 10^{-7} \mathrm{~mol} \mathrm{~L}^{-1}$, respectively.

Determination of catechin in green tea using the biomimetic sensor and capillary electrophoresis

In order to evaluate the applicability of the biomimetic sensor the three samples of green tea were used in the 


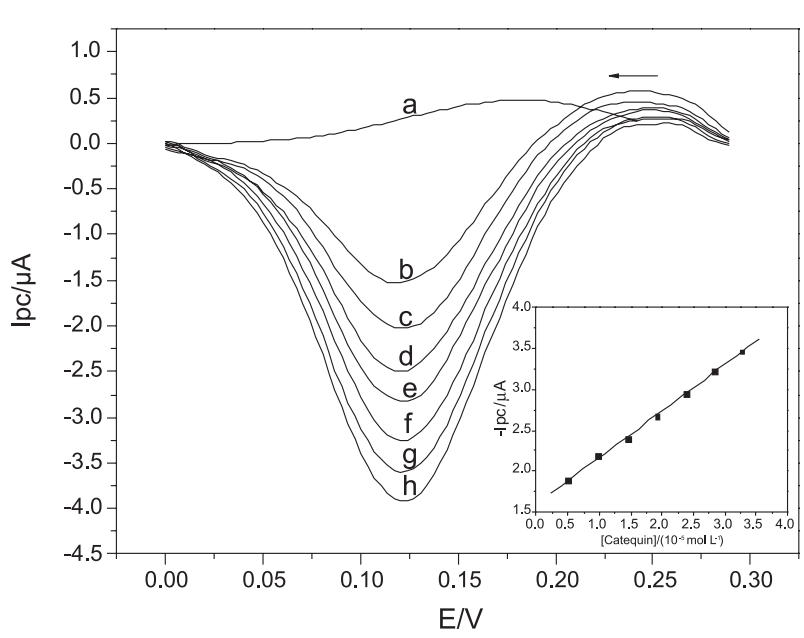

Figure 5. Square wave voltammograms obtained using the proposed biomimetic sensor for (a) blank in phosphate buffer solution, and catechin solutions at the following concentrations: (b) $4.95 \times 10^{-6}$; (c) $9.80 \times 10^{-6}$; (d) $1.45 \times 10^{-5}$; (e) $1.92 \times 10^{-5}$; (f) $2.38 \times 10^{-5}$; (g) $2.83 \times 10^{-5}$; (h) $3.27 \times 10^{-5} \mathrm{~mol} \mathrm{~L}^{-1}$, at pulse amplitude $80 \mathrm{mV}$, frequency $30 \mathrm{~Hz}$ and increment $3.3 \mathrm{mV}$. Inset: the analytical curve of the biomimetic sensor.

quantitative determination of catechin applying the standard additions method to overcome the matrix effects. Dalluge and Nelson ${ }^{1}$ have reported catechin content in a green tea infusion of 9 to $117 \mathrm{mg} \mathrm{g}^{-1}$ (tea leaves). The results obtained using the proposed biomimetic sensor were close to those obtained by the capillary electrophoresis method (Table 4). Figure 6A shows the electropherogram of the green tea sample and Figure 6B the electropherogram of standard solution together with the internal standard. As can be seen from the data, the results are in agreement at a 95\% confidence level, within an acceptable range of error, and it can thus be concluded that the biomimetic sensor is suitable for this application.

Table 4. Determination of catechin in green tea using the biomimetic sensor and capillary electrophoresis

\begin{tabular}{lccc}
\hline Sample & \multicolumn{2}{c}{ Catechin/(mg L } \\
& Biomimetic sensor & Capillary electrophoresis & $\begin{array}{c}\text { Relative } \\
\text { error/(\%) }\end{array}$ \\
\hline A & $160.0 \pm 0.1$ & $159.2 \pm 0.1$ & -0.50 \\
A & $155.2 \pm 0.2$ & $159.1 \pm 0.1$ & +2.45 \\
B & $81.3 \pm 0.2$ & $93.0 \pm 0.1$ & +12.6 \\
C & $80.1 \pm 0.1$ & $88.2 \pm 0.1$ & +9.18 \\
\hline
\end{tabular}

$* n=4$; confidence level of $95 . \mathrm{R}_{\mathrm{e}}=$ biomimetic sensor $v s$ capillary electrophoresis.

\section{Conclusions}

This study demonstrated that the novel dinuclear copper(II) complex was successfully employed to mimic the active site of the catechol oxidase enzyme and that the proposed biomimetic sensor is a feasible alternative for the

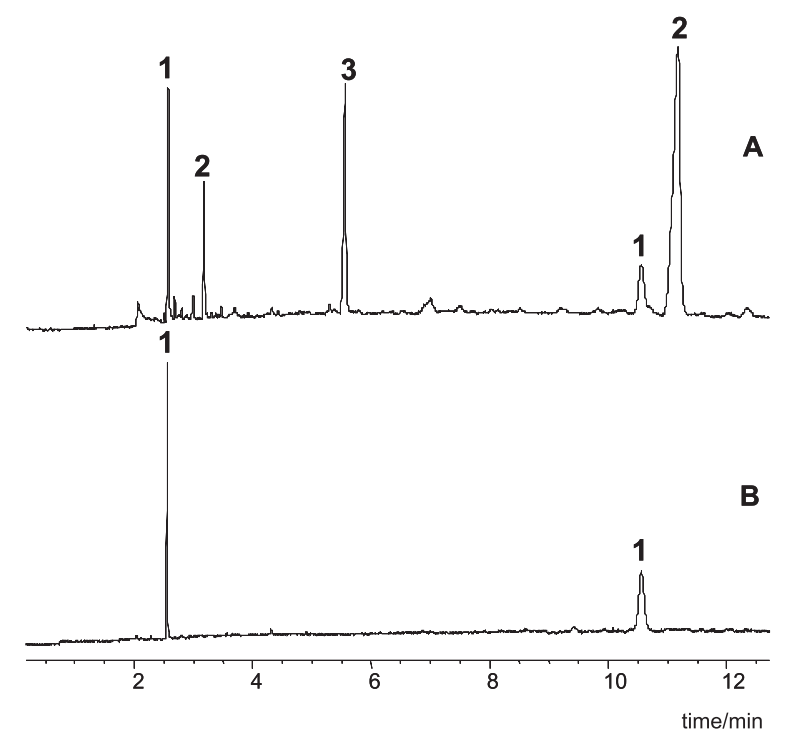

Figure 6. (A) Electropherogram of sample. (B) Electropherogram of standard solution. Conditions: $50.0 \times 10^{-3} \mathrm{~mol} \mathrm{~L}^{-1}$ sodium dodecylsulfate, $10.0 \times 10^{-3} \mathrm{~mol} \mathrm{~L}^{-1}$ triethylamine, $\mathrm{pH} 2.5$ adjusted with phosphoric acid, $25^{\circ} \mathrm{C}$, uncoated fused-silica capillary $(48.5 \mathrm{~cm} \times 50 \mu \mathrm{m}$ I.D. $\times$ $375 \mu \mathrm{m}$ O.D, $40 \mathrm{~cm}$ of effective length), injected hydrodynamically at 50 mbar for $3 \mathrm{~s}$, applied separation voltage $25 \mathrm{kV}$, negative polarity. The detector wavelength was $206 \mathrm{~nm}$. Peak identification: 1 - Catechin and 2 - Caffeine.

analytical determination of catechin. This sensor showed excellent electrochemical characteristics and analytical performance. In addition, it has the benefits of low cost and simplicity of construction.

\section{Acknowledgments}

Financial support from CNPq (Process 472169/2004-1 and 472541/2006-4), MCT/CNPq/PADCT, FAPESC and also scholarships granted by CNPq to SCF and REMBO are gratefully acknowledged.

\section{References}

1. Dalluge, J. J.; Nelson, B. C.; J. Chromatogr. A 2000, 881, 411.

2. Wang, H.; Provan, G. J.; Helliwell, K.; Food Chem. 2003, 81, 307.

3. Nishitani, E.; Sagesaka, Y. M.; J. Food Compos. Anal. 2004, 17,675 .

4. Schulz, H.; Engelhardt, U.H.; Wegent, A.; Drews, H. H.; Lapczynski, S.; J. Agric. Food Chem. 1999, 47, 5064.

5. Lee, B-L.; Ong, C.; J. Chromatogr., A 2000, 881, 439.

6. Wang, H.; Helliwell, K.; You, X.; Food Chem. 2000, 68, 115.

7. Khokhar, S.; Venema, D.; Hollman, P. C. H.; Dekker, M.; Jongen, W.; Cancer Lett. 1997, 114, 171.

8. Arce, L.; Ríos, A.; Valcárcel, M.; J.Chromatogr. A 1998, 827, 113. 
9. Weiss, D. J.; Austria, E. J.; Anderton, C. R.; Hompesch, R.; Jander, A.; J. Chromatogr. A 2006, 1117, 103.

10. Selmeczi, K.; Réglier, M.; Giorgi, M.; Speier, G.; Coord. Chem. Rev. 2003, 245, 191.

11. Mahadevan, V.; Gebbink, R. J. M. K.; Stack, T. D. P.; Curr. Opin. Chem. Biol. 2000, 4, 228.

12. Sotomayor, M. D. P. T.; Tanaka, A. A.; Kubota, L. T.; J. Electroanal. Chem. 2002, 536, 71.

13. Sotomayor, M. D. P. T.; Tanaka, A. A.; Kubota, L. T.; Electrochim. Acta 2003, 48, 855.

14. Ebavia, B. S.; Carbanilla, S.; Sevilla III, F.; Talanta 2005, 66, 145.

15. Than, R.; Feldmann, A.; Krebs, B.; Coord. Chem. Rev. 1999, 182, 211.

16. Belle, C.; Pierre, J.-; Eur. J. Inorg. Chem. 2003, 23, 4137.

17. Fernandes, C.; Neves, A.; Bortoluzzi, A. J.; Mangrich, A. S.; Rentschler, E.; Szpoganicz, B.; Schwingel, E.; Inorg. Chim. Acta. 2001, 320, 12.

18. Neves, A.; Rossi, L. M.; Bortoluzzi, A. J.; Mangrich, A. S.; Haase, W.; Werner, R.; J. Braz. Chem. Soc. 2001, 12, 747.

19. Neves, A.; Rossi, L. M.; Bortoluzzi, A. J.; Szpoganicz, B.; Wiezbicki, C.; Schwingel, E.; Inorg. Chem. 2002, 41, 1788.

20. Rossi, L. M.; Neves, A.; Bortoluzzi, A. J.; Hörner, R.; Szpoganicz, B.; Terenzi, H.; Mangrich, A. S.; Maia, E. P.; Castellano, E. E.; Haase, W.; Inorg. Chim. Acta 2005, 358, 1807.

21. dos Anjos, A.; Bortoluzzi, A. J.; Osório, R. E-H. M. B.; Peralta, R. A.; Friedermann, G. R.; Mangrich, A. S.; Neves, A.; Inorg. Chem. Comm. 2005, 8, 249.
22. dos Anjos, A.; Bortoluzzi, A. J.; Szpoganicz, B.; Caro, M. S. B.; Friedermann, G. R.; Mangrich, A. S.; Neves, A.; Inorg. Chim. Acta 2005, 358, 3106.

23. Osório, R. E-H. M. B.; dos Anjos, A.; Bortoluzzi, A. J.; Mangrich, A. S.; Neves, A.; unpublished results (2008).

24. Neves, A.; dos Anjos, A.; Bortoluzzi, A. J.; Szpoganicz, B.; Schwingel, E. W.; Mangrich, A. S.; Inorg. Chim. Acta 2003, $356,41$.

25. Neves, A.; Erthal, S. M. D.; Drago, V.; Griesar, K.; Haase, W.; Inorg. Chim. Acta 1992, 197, 121.

26. Oliveira, I. R. W. Z.; Osório, R. E-H. M. B.; Neves, A.; Vieira, I. C.; Sens. Actuators, B 2007, 122, 89.

27. Oliveira, I. R. W. Z.; Fernandes, S. C.; Vieira, I. C.; J. Pharm. Biomedical. Anal. 2006, 41, 366.

28. Fernandes, S. C.; Oliveira, I. R. W. Z.; Vieira, I. C.; Enzyme Microb. Technol. 2007, 40, 661.

29. Oliveira, I. R. W. Z.; Vieira, I. C.; Quim. Nova 2006, 29, 932.

30. Oliveira, I. R. W. Z.; Vieira, I. C.; Enzyme Microb. Technol. 2006, $38,449$.

31. Agboola, B.; Nyokong, T.; Talanta 2007, 72, 691.

32. Agboola, B.; Nyokong, T.; Anal. Chim. Acta 2007, 587, 116.

33. Agboola, B.; Nyokong, T.; Electrochim. Acta 2007, 52, 5039.

34. Agboola, B.; Westbroek, P; Ozoemena, K. I.; Nyokong, T.; Electrochem. Comm. 2007, 9, 310.

35. Sephlotho, N.; Nyokong, T.; Zagal, J. H.; Bedioui, F.; Electrochim. Acta 2006, 51, 5125.

Received: April 30, 2007 Web Release Date: July 31, 2008 